\title{
Rethinking Muhammadiyah: Masjid, Teologi Dakwah Dan Tauhid Sosial (Perspektif Filsafat Dakwah)
}

\author{
Robby H. Abror \\ UIN Sunan Kalijaga Yogyakarta \\ E-mail: robby_abror23@yahoo.com
}

\begin{abstract}
As a dakwah movement that has a social ideals to bring the genuine Islamic community is the basic philosophical of Muhammadiyah's movement. There are three important concepts such as, the movement of jama'a, qaryah tayyibah and sakinah family. Then came the strategy of "cultural da'wah" and look at the reality of the importance of greeting compound. In addition, the need to emphasize the contemporary missionary preaching bi alkitâbah, in addition to bi-lisân al-hâl. Brilliant thinking regarding the function and existence redefined mosque, theology, preaching and social monotheism is needed to revitalize the spirit of the mission within the framework of philosophical-rational.
\end{abstract}

\section{Kata kunci:}

Muhammadiyah, filsafat, dakwah, masjid, tauhid sosial

\section{A. Pendahuluan}

Matahari yang terbit dari kota Ngayogyakarta Hadiningrat itu telah menyinari seluruh pelosok negeri ini bahkan memantulkan cahayanya ke penjuru dunia. Dialah persyarikatan yang dikenal dengan nama Muhammadiyah, didirikan oleh K.H. Ahmad Dahlan (1868-1923) pada 18 November 1912 di Yogyakarta. Gerakan ini dapat dipetakan dalam tiga identitas, yakni sebagai gerakan Islam, gerakan dakwah Islam dan gerakan tajdid. Kajian pendirinya terhadap beberapa ayat al-Quran memantulkan semangat gerakan Islam, sebagaimana tertuang dalam buku K.R.H. Hadjid (2011), Ajaran K.H. A. Dahlan dengan 17 Kelompok Ayat-ayat al-Quran. Muhammadiyah juga mendirikan berbagai amal usaha, seperti TK ABA (Taman Kanak-kanak 'Aisyiah Busthanul Athfal) hingga PTM (Perguruan Tinggi Muhammadiyah), Rumah Sakit, Panti 
Asuhan, dsb. tidak lain dijadikan sebagai sarana dan wahana dakwah Islam. Sedangkan sebagai gerakan tajdid, Muhammadiyah melakukan dua hal penting: pemurnian (purifikasi) dan pembaharuan (reformasi) (Pasha dan Darban, 2003: 160-163).

Nashir (2001: 70-71) menambahkan penekanan bahwa Muhammadiyah sebagai ideologi gerakan Islam dengan mengajukan lima alasan yang rasional: (1) alam pikiran Muhammadiyah telah menjadi gerakan (harakah) yang membedakan dengan yang lain; (2) memiliki doktrin gerakan dalam Muqaddimah Anggaran Dasar Muhammadiyah, Kepribadian Muhammadiyah, Matan Keyakinan dan Cita-cita Hidup Muhammadiyah, Khittah Muhammadiyah; Pedoman Hidup Islami Warga Muhammadiyah; (3) menjadi organisasi yang mapan dengan sistem gerakan yang terorganisir; (4) memiliki penganut dalam jumlah besar; dan (5) bercita-cita sosial untuk wujudkan masyarakat Islam yang sebenar-benarnya.

Sebagai gerakan dakwah Islam yang mempunyai cita-cita sosial mewujudkan masyarakat Islam yang sebenar-benarnya merupakan dasar filosofi dakwah Muhammadiyah. Artinya apapun yang digagas dan dilakukan oleh Muhammadiyah merupakan representasikan gerakan dakwah Islam dan diarahkan untuk pencapaian cita-cita tersebut. Sholeh (2005, 64-65) menegaskan bahwa melalui gerakan dakwah jama'ah, Muhammadiyah ingin menawarkan solusi alternatif atas pelbagai masalah dan tantangan yang dihadapi masyarakat dengan cara menggerakkan segenap anggotanya di lingkungan tempat tinggal mereka untuk mengambil prakarsa dan membangun kehidupan bersama dengan masyarakat lainnya. Aktivitas dakwahnya dapat dilakukan di berbagai bidang seperti pendidikan, sosial (kesehatan dan kemanusiaan), ekonomi, kebudayaan, hukum dan hubungan luar negeri.

Bahtiar (2004: 35-37) mengingatkan bahwa bukan hanya Majelis Tabligh saja yang bertanggung jawab dalam masalah dakwah Muhammadiyah, tetapi seluruh lembaga-lembaga amal usaha lainnya juga ikut berdakwah. Ia ingin menandaskan kembali pentingnya kewajiban dakwah bagi seluruh pengurus dan warga Muhammadiyah, karena identitas gerakan ini adalah gerakan Islam dakwah amar ma'ruf nahi munkar. Jika kesadaran atas tanggung jawab dakwah dapat dilakukan semua pihak dan lembaga hal ini akan memungkinkan optimalisasi dan sinergi gerakan dakwah Muhammadiyah. 
Usaha mengoptimalkan gerakan dakwah Muhammadiyah dirumuskan sejak Muktamar ke-38 di Ujungpandang pada 1971 dan secara berturut-turut hingga Muktamar ke-41 di Surakarta pada 1985, memutuskan tiga konsep gerakan, yaitu gerakan jama'ah dan dakwah jama'ah, keluarga sakinah dan qaryah thayyibah. Yang menarik kemudian adalah munculnya istilah "dakwah kultural". Sebenarnya istilah itu merupakan kelanjutan dari tiga program tersebut. Nashir dan Maarif (2005: v) menjelaskan bahwa gagasan konsep "dakwah kultural" telah diputuskan dalam Sidang Tanwir di Denpasar, Bali pada 2002 dan Tanwir di Makassar pada 2003. Dalam buku itu (2005: 27), dakwah kultural didefinisikan sebagai "upaya menanamkan nilai-nilai Islam dalam seluruh dimensi kehidupan dengan memperhatikan potensi dan kecenderungan manusia sebagai makhluk budaya secara luas, dalam rangka mewujudkan masyarakatkan Islam yang sebenar-benarnya". Strategi dakwah kultural tersebut dapat diterapkan dalam konteks budaya lokal, budaya global, melalui apresiasi seni, melalui multimedia (media cetak, radio dan televisi, internet, telepon genggam dan buku harian elektronik, serta melalui gerakan jama'ah dan dakwah jamaah (GJDJ).

Dalam faktanya, strategi dakwah kultural ini melahirkan multitafsir, termasuk dari pihak-pihak yang "mencurigai" gagasan tersebut, karena itu, menurut Jabrohim (2005: 67), gagasan atau strategi itu perlu dibumikan. Muchlas (2006) juga mencoba memberikan landasan bagi dakwah kultural dengan upayanya membaca respon alQuran terhadap adat kebiasaan Arab jahiliyah, tetapi tulisannya lebih mengesankan reduksi dan justifikasi atas gagasan dakwah kultural. Pendapat yang lebih terbuka dipaparkan oleh Bahtiar (2003: 185), menurutnya bahwa dakwah kultural itu lebih relevan disebut sebagai reafirmasi, yakni penegasan ulang bahwa Muhammadiyah itu adalah juga gerakan kebudayaan.

\section{B. Metode Dakwah Kontemporer}

Berbagai literatur ilmu dakwah selalu merujuk pada ayat yang sering dijadikan landasan filosofis bagi para da'i yaitu Q.S. an-Nahl: 125, yang membagi tiga metode dakwah: (1) al-hikmah (berdakwah dengan bijaksana, budi mulia, benar dan berhati bersih); (2) al-mau'idzah alhasanah (memberi pengajaran, bimbingan atau pendidikan yang baik); dan (3) al-mujadalah bi al-lati hiya ahsan (berdialog atau bertukar 
pendapat yang baik). Dalam menjalankan metode tersebut perlu dibarengi dengan mengindahkan "kode etik dakwah" (Suparta dan Hefni, 2003: 82-92) di antaranya adalah: (1) ucapan dan perbuatan harus sama; (2) melakukan toleransi agama yang dibenarkan; (3) tidak menghina sesembahan non-Muslim; (4) adil, sederajat, dan tidak diskriminatif; (5) tidak memungut imbalan; (6) tidak berteman dengan pelaku maksiat; dan (7) punya bekal ilmu cukup dan tidak menyampaikan sesuatu yang tidak diketahui.

Kode etik dakwah sebenarnya bagian dari etika dalam Islam sebagaimana tertuang dalam al-Quran dan Hadits, sehingga dapat dikembangkan lagi dalam praktiknya. Sayyid Nuh (2004: 91-155) memberikan kiat-kiat dakwah yang strategis, menurutnya ada beberapa hal yang perlu diperhatikan, di antaranya ialah: menjadikan hidup sebagai sarana dakwah dan pendidikan Islam; menyampaikan dakwah hendaknya melalui pemahaman dan praktik yang menyeluruh, sinergis dan seimbang; dan tidak tenggelam pada sesuatu yang tidak bermanfaat.

Selain itu, dikenal pula metode dakwah yang berdasarkan pada kerja nyata yaitu dakwah bi lisân al-hâl, yakni berdakwah dengan perbuatan yang konkret. Seperti ungkapan hikmah yang berbunyi lisan al-hal afsahu min lisân al-maqâl, kenyataan itu lebih fasih daripada ucapan. Muriah (2000: 72) menyebutnya sebagai model dakwah kontemporer, karena berdasar pada keteladanan (uswah/qudwah). Ada pula yang membaginya menjadi tiga: dakwah bi al-kitabah (dengan tulisan); bi al-lisân; dan bi al-hikmah (Faqih, dkk: 5-10).

Lembaga Pengkajian dan Pengamalan Islam Universitas Muhammadiyah Yogyakarta (LPPI UMY) telah melakukan terobosan dakwah bi al-kitâbah yang baik, salah satunya dengan menerbitkan buku Islamisasi Kampus dan IImu Pengetahuan (2002), sebuah usaha memberikan panduan bagi para mahasiswa dan seluruh sivitas akademika. Selain UMY, Universitas Ahmad Dahlan (UAD) juga memiliki Lembaga Pengkajian Studi Islam (LPSI), di samping bertanggung jawab mendistribusikan dosen-dosen AIK (Agama Islam dan Kemuhammadiyahan) juga mengelola pondok pesantren dan kajiankajian keislaman secara rutin.

Fathi Yakan, seorang tokoh gerakan dakwah terkemuka, mengingatkan kita bahwa para da'i dapat menjadi penyebab runtuhnya dakwah itu sendiri. Yakan (2005: 94-139) menyumbangkan pemikiran penting bagi tentang cara bagaimana menjaga bangunan dakwah: (1) 
tegakkan bangunan di atas landasan taqwa kepada Allah; (2) kukuhkan ukhuwah karena Allah; (3) saling wasiat dalam kebenaran; (4) tegakkan tradisi syura; (5) menjalin hubungan dengan penuh rasa cinta dan kasih sayang; (6) tegakkan landasan sukarela dalam bekerja; (7) sungguhsungguh dalam menjaga nilai-nilai syari'at dan dakwah; (8) tegakkan aktivitas di atas perencanaan (takhthit) dan manajemen (tandzim); dan (9) prinsip salign melengkapi dan seimbang.

Dalam tulisan ini akan kita lihat bagaimana tiga pemikir Muhammadiyah melakukan tajdid sehingga dapat memberikan pengaruh dan kontribusi yang signifikan bagi generasi da'i sesudah mereka. Saya akan mencoba untuk mengelaborasi gagasan orisinal dari tiga pemikir dan pelaku dakwah Muhammadiyah: Kuntowijoyo, Abdul Munir Mulkhan dan M. Amien Rais dalam tulisan yang singkat berikut ini.

\section{Kuntowijoyo: Masjid, Musyarakah, dan Beda antara yang cumulative dan non-cumulative}

Kuntowijoyo dilahirkan di Yogyakarta pada 18 September 1943. Gelar Ph.D dalam ilmu sejarah dia peroleh dari Universitas Columbia, Amerika Serikat pada 1980. Sebagai sejarawan, beliau concern pada berbagai kajian lintas disiplin ilmu, termasuk dakwah. Baginya Masjid harus menjadi pusat perubahan sosial. Dalam buku Dinamika Sejarah Umat Islam Indonesia (1985) ia menulis dua tulisan penting: "Masjid sebagai Pusat Gerakan" serta "Musyarakah dan Jama'ah". Menurutnya (1985: 120-121), masjid belum berperan untuk memfungsikan keberadaannya dalam membina jama'ah di wilayahnya masing-masing, disebabkan adanya solidaritas polity-solidaritas insidental dan temporal yang terjebak pada politik dan Pemilu. Baginya, umat Islam masih mengapung, tidak mempunyai basis paling bawah. Adanya $\mathrm{Ta}^{\prime} \mathrm{mir}$ Masjid belum menjamin partisipasi aktif jama'ah baik dalam kepengurusan maupun aktivitas Masjid itu sendiri. Bahkan jama'ah ditarik masuk partai politik sehingga dapat merusak komitmen dakwah umat. Seharusnya umat wajib bersatu dalam masjid tanpa kepentingan politik, karena itu dapat terbelenggu dalam politisasi dakwah. Dengan demikian, jama'ah sudah seharusnya bertekad memupuk dan mengembangkan solidaritas sosial dan solidaritas ekonomi. Maksudnya adalah bahwa umat disatukan oleh ibadah sekaligus oleh nasib sosial dan nasib ekonomi yang sama. 
Selain itu, ia juga menyarankan untuk menjalankan ajaran musyarakah yang menurutnya mengambil model di zaman Nabi Muhammad saw. Musyarakah bukan komune yang membagi alat-alat produksi kerja, dan distribusi sebagaimana ajaran Karl Marx. Menurut Kuntowijoyo, musyarakah hanya bisa dilaksanakan dengan kesadaran yang tinggi dalam suatu jama'ah untuk membagi cinta kasih, kesejahteraan dan kecerdasan. Redistribusi kekayaan dalam musyarakah semata-mata karena Allah swt. Kuntowijoyo (1985: 133-134) mendefinisikan musyarakah sebagai berikut,

Ajaran musyarakah adalah suatu ketentuan bahwa orang-orang miskin, yaitu mereka yang karena kedudukan sosial-ekonomis tidak mempunyai akses terhadap pasaran barang dan jasa dalam masyarakat, mempunyai hak untuk mengambil bagian dalam proses distribusi barang dan jasa tanpa harus memberikan gantinya. Ajaran ini dimaksudkan untuk mengurangi atau menandingi kecenderungan individualisme dari masyarakat kontraktual. Kecenderungan untuk hidup sendiri-sendiri dalam masyarakat modern yang hanya berpusat pada keluarga, diperluas secara sukarela dengan ajaran ini.

Mengenai mekanisme kerja dalam kelompok musyarakah harus sangat sederhana supaya tidak mirip dengan sebuah birokrasi, jama'ah musyarakah bukan merupakan organisasi, tetapi sebuah keluarga besar. Pembentukan dan pembinaan jama'ah menghendaki anggota yang tetap, yaitu mereka yang tinggal di sekitar masjid. Gagasannya tentang musyarakah sebenarnya hanya ingin mendorong sikap konsisten dengan pemahaman bahwa menegakkan peranan masjid dalam dunia modern harus mengingat kepentingan umat yang mendesak, yakni sumbangannya kepada rasa aman sosial-ekonomis para jama'ahnya (Kuntowijoyo, 1985: 136-137).

Selain itu, Kuntowijoyo juga menyumbang pemikiran penting sebagaimana tertuang dalam bukunya Islam sebagai Ilmu (2004). Ia berpendapat bahwa kebenaran itu sifatnya non-cumulative, sedangkan kemajuan itu cumulative. Misalnya, shalat selalu bersifat non-cumulative, sedangkan sains itu cumulative. Sejak zaman Rasulullah Saw, shalat tidak pernah berubah sampai akhir zaman. Shalat itu dimulai dari takbir dan diakhiri salam, seterusnya harus demikian. Tetapi ilmu pengetahuan dan teknologi bisa berubah. Misalnya, jumlah planet yang semula 9 buah, saat ini ditetapkan tinggal 8 buah. Pluto sudah tidak lagi dianggap sebagai 
planet (karena terlalu kecil dan tidak berada pada garis peredaran). Satu hari nanti sangat bisa jadi akan berubah lagi karena sifatnya cumulative tadi. Umat Islam sering terlibat dalam perselisihan yang cukup keras dan tajam hanya karena memegang teguh dan mempertahankan prinsipnya masing-masing (dan terkadang "memaksakannya" kepada orang lain). Satu contoh, ada seorang ulama yang memegang teguh prinsip bahwa belajar itu harus di masjid, bukan di kelas (meskipun ada kelas/ruangan di sebuah pesantren atau tempat para santri menuntut ilmu). Dengan dalih bahwa yang demikian itu telah menjadi tradisi ulama sejak dulu dan diyakini bisa menyebabkan ulama menjadi pintar dan alim dengan segala kesederhanaannya. Alasan lainnya, karena kelas itu termasuk salah satu bid'ah. Di situ terdapat "barang-barang aneh": OHP/LCD, AC dan alat-alat pembelajaran lainnya yang tidak pernah diajarkan Nabi (Abror, 2006: 32).

Pendapat ini pada satu sisi memang perlu dihargai, karena seorang ulama biasanya memiliki suatu keyakinan yang telah teruji meskipun pada umumnya ditentang oleh banyak orang. Tetapi di sisi lain, pemahaman ini bisa mempersempit cara pandang terhadap pentingnya kemajuan bagi proses belajar-mengajar yang mensyaratkan "banyak hal". Mengkaji kitab memang tidak butuh banyak hal, cukup duduk bersila dan menyimak. Tetapi dalam perkembangan zaman, hal ini tentu perlu dikembangkan lebih lanjut. Logikanya, bahwa ilmu pengetahuan itu bisa berubah. Belajar itu syarat dengan ilmu pengetahuan. Maka cara belajar itu harus berubah menjadi lebih baik lagi. Belajar itu wajib, tapi sifat wajibnya tidak sama persis dengan shalat. Shalat itu wajib dengan pahala tertentu yang telah ditetapkan oleh Allah Swt dan karena memang ia bersifat non-cumulative, sedangkan belajar juga wajib bisa jadi lebih banyak pahala yang dilimpahkan, tetapi sifatnya cumulative. Sehingga perlu dipahami pentingnya kewajiban keduanya dalam proporsi yang berbeda dalam perspektif Kuntowijoyoian (Abror, 2006: 32).

Shalat dan masjid itu sangat dekat sekali artinya dan disebutkan oleh Rasulullah Saw. Misalnya, salah satu orang yang paling dirindukan surga adalah pemuda yang hatinya tertambat di masjid. Berarti ada pesan moral di situ bahwa, seseorang diperintahkan untuk menjalankan shalat (berjama'ah) di masjid. Menjalankan shalat itu wajib (dan tata caranya tidak boleh diubah-ubah), sedangkan masjid sebagai tempat shalat boleh diubah-ubah, diperindah, diberi kipas angin/AC, dilengkapi dengan pengeras suara, bahkan saat ini telah dikembangkan sebagai bagian 
integral dari kebutuhan bermasyarakat. Di situ tersedia mobil jenazah, koperasi tempat berjual beli, ruangan untuk Taman Pendidikan Al-Qur'an (TPA), dan masih banyak lagi. Menjadi jelas bahwa masjid, karena menjadi bagian dari ilmu pengetahuan dan kebudayaan tertentu dengan corak yang mungkin dibangun secara berbeda-beda (antara arsitektur Turki berbeda dari masjid Tiongkok atau masjid Jawa), sifatnya selalu cumulative. Sedangkan shalat adalah hal lain yang koheren dilaksanakan di dalam bangunan masjid dan selalu bersifat non-cumulative (Abror, 2006: 32).

Shalat itu pekerjaan yang mudah bagi orang yang khusyu'. Shalat identik dengan kekhusyu'an. Khusyu' dalam shalat adalah sesuatu yang bersifat non-cumulative. Saat ini ada semacam "pelatihan keagamaan" yang "bisa dijual" dalam hal shalat. Contohnya, sekarang ada pelatihan shalat khusyu'. Kegiatan ini seolah-olah menunjukkan bahwa shalat merupakan hal khusus yang hanya dikuasai oleh segelintir orang, sebegitu perlunya sehingga segelintir orang itu memasarkan cara-cara shalat yang khusyu' kepada orang lain. Kita bisa memaklumi, karena kegiatan ini bersifat cumulative. Dalam manhaj dakwah Rasulullah Saw, beliau mengajarkan shalat di Makkah secara gratis dan penuh ketulusan di bawah bayang-bayang ancaman dari kaum kafir Quraisy yang pagan. Metode pembelajaran Rasulullah Saw pastinya sudah menyinggung soal kekhusyu'an dalam praktek shalat. Tetapi zaman sudah berubah, pada saat ini seseorang bisa mengelola cara atau metode itu sehingga bisa bernilai jual sekaligus bernilai ibadah. Dalam masa yang lain, mungkin saja, cara atau metodenya berubah, tetapi shalatnya tetap. Contoh lain, dzikir kepada Allah Swt adalah urusan yang penting untuk masingmasing individu Muslim. Sehingga bagi siapapun yang merindukan ketenangan hati, maka baginya perlu berdzikir mengingat-Nya. Ketenangan hati identik dengan dzikir. Saat ini ada semacam "pelatihan mengelola kecerdasan spiritual". Berdzikir adalah urusan pribadi, hal yang seharusnya biasa dilakukan oleh seorang Muslim. Tetapi sekarang, untuk mendapatkan ketenangan hati agar bisa dekat kepada Allah Swt, seseorang perlu mengeluarkan uang untuk "membeli" cara atau metodenya (dan itu tidak murah) (Abror, 2006: 33).

Sesungguhnya apa yang baru dan berbeda dari hal-hal tersebut? Bahwa ternyata shalat dan dzikir itu sifatnya non-cumulative, tidak berkembang dan memang seharusnya demikian, sehingga sejak zaman Rasulullah Saw sampai akhir zaman tetap (di)lestari(kan). Sedangkan 
pelatihan, metode atau pendekatannya bersifat cumulative, bisa berubah-ubah, bisa bertambah dan berkurang. Substansinya tetap bahwa seorang Muslim wajib menunaikan shalat lima waktu dan perlu berdzikir, meskipun caranya berbeda-beda. Ketika penentuan 1 Syawal berbeda antara satu ulama atau golongan dengan ulama atau golongan lainnya, maka hal itu menjadi wajar dan biasa-biasa saja. Karena cara atau kegiatan menentukan (baik yang menggunakan hisab maupun ru'yatul hilal) hari " $\mathrm{H}$ " Idul Fitri itu bersifat cumulative maka tidak perlu diributkan dan dipermasalahkan. Karena intinya sama, bahwa yang penting adalah shalat Idul Fitrinya, dan itu non-cumulative. Pendirian berdasarkan pedoman yang telah dipegang teguh harus dipahami sebagai hal yang cumulative (Abror, 2006: 33).

Dalam kehidupan sehari-hari, sering timbul perbedaan dalam memahami urusan ukhrawi maupun duniawi. Ada orang yang hanya mengganggap penting urusan akhirat saja sehingga tidak mementingkan urusan duniawi, dan begitu pula sebaliknya. Padahal masing-masing punya nilainya tersendiri yang bisa dipersembahkan kepada Allah Swt. Pandangan yang seimbang bisa disimak dalam doktrin berikut, "shalatlah kamu seolah-olah kamu mati besok dan bekerjalah kamu seolah-olah kamu hidup untuk selamanya!" Urusan akhirat bila dibuat garis vertikal sering disebut teosentrisme (hablum min Allâh) di situlah terletak ibadahibadah mahdhoh, sedangkan urusan dunia bergaris horizontal lebih bermakna antroposentrisme (hablum min an-nâs) di situ terletak ibadahibadah ghairu mahdhoh. Seorang Mukmin adalah seorang Muslim yang menjalankan keduanya secara seimbang. Ibadah mahdhoh terkait erat dengan hal-hal yang bersifat non-cumulative, biasanya memang kaku dan stagnan. Sedangkan ibadah ghairu mahdhoh lekat dengan hal cumulative, selalu menantang dan dinamis. Abu al-Darda' diingatkan oleh sahabatnya yang bernama Salman al-Farisi, karena istrinya sering mengeluhkan ulah suaminya yang sudah tidak lagi memerlukan dunia. Abu al-Darda' lebih mementingkan hak Tuhannya ketimbang memenuhi hak istrinya. Padahal masing-masing mempunyai haknya secara seimbang. Bahkan Rasulullah Saw membenarkan Salman (HR Bukhari dari Abu Juhaifah). Karena tidak mampu menyeimbangkan hak antara keduanya, Abu alDarda' harus mengoreksi ibadahnya (Abror, 2006: 33).

Dalam kisah lain disebutkan bahwa ada tiga pria yang punya semangat beribadah yang terlalu berlebihan. Ada yang bertekad ingin shalat malam seumur hidupnya, ada yang ingin berpuasa sepanjang 
tahun hingga mati dan ada yang ingin menghindari perempuan untuk tidak menikah selamanya demi mendekatkan diri kepada Allah Swt. Padahal Rasulullah kadang-kadang berpuasa sunnah kadang tidak, kadang-kadang shalat malam kadang tidur, dan beliau menikahi perempuan (HR Bukhari dari Anas bin Malik). Ada juga anak muda bernama 'Abdullah bin 'Amr bin al-'Ash yang bersumpah akan berpuasa sepanjang hari dan shalat setiap malam sepanjang hayatnya. Rasulullah mengingatkannya, bahwa tubuhmu, matamu, istrimu dan tamumu punya hak atas dirimu. (HR Bukhari dari 'Abdullah bin 'Amr). Sikap berlebihlebihan (ghuluw) dalam beribadah dilarang oleh Rasulullah Saw. Allah Swt berfirman, "jangan berlebih-lebihan dalam agamamu" (wa lâ taghlû fî dînikum) (Abror, 2006: 33).

Seorang mu'min harus berusaha untuk meletakkan sesuatu pada tempatnya (wad'u al-syai' fi mahallihi). Shalat itu wajib dan merupakan ibadah mahdzoh yang amat penting, tetapi menolong orang lain, menghormati tetangga, menyambung tali silaturahim, mengelola alam dan realitas sosial merupakan ibadah ghairu mahdzah yang juga tidak kalah pentingnya. Maka kalimat dalam al-Qur'an yang berbunyi, min atsari al-sujud bukan dimaknai sebagai adanya "cap di dahi/bekas sujud", tetapi lebih kepada pentingnya memanifestasikan makna sujud (shalat) itu dalam kehidupan kita sehari-hari. Kebenaran (shalat) itu harus selaras dengan kemajuan (manifestasinya) (Abror, 2006: 33).

\section{Abdul Munir Mulkhan: Teologi Dakwah dan Islam Murni}

Abdul Munir Mulkhan lahir di Jember pada 13 November 1946. Meraih doktornya dalam bidang sosiologi diraih di Universitas Gadjah Mada (UGM). Dalam bukunya Teologi Kebudayaan dan Demokrasi Modernitas terdapat dua gagasannya yang membicarakan tentang dakwah, yaitu: "Religiusitas, Dakwah Pengembangan dan Pemberdayaan Masyarakat" serta "Pembaharuan Teologi Dakwah".

Dalam pandangannya bahwa dakwah amar ma'ruf nahi munkar harus merupakan bagian integral dari pengembangan kehidupan kemasyarakatan sebagai realisasi keberagamaan. Baginya, strategi dakwah pengembangan masyarakat merupakan bagian dari usaha menyelesaikan berbagai persoalan kehidupan kemasyarakatan dan kebangsaan yang terus timbul dan berkembang. Dakwah Islam harus terus berusaha merumuskan dan menawarkan peradaban yang kreatif (Mulkhan, 1995: 4-9). 
Menurut Mulkhan (1995: 26) bahwa konsep dan strategi dakwah pemecahan masalah dimaksudkan bahwa kegiatan dakwah harus merupakan usaha memecahkan atau menyelesaikan persoalan kehidupan umat dan masyarakat di bidang sosial-budaya, ekonomi dan politik dalam kerangka masyarakat modern industiral. Yang nantinya diharapkan menghasilkan tiga kondisi: (1) tumbuhnya kepercayaan dan kemandirian umat dan masyarakat sehingga berkembang sikap optimis; (2) tumbuhnya kepercayaan terhadap kegiatan dakwah guna mencapai tujuan kehidupan yang lebih ideal; (c) berkembangnya suatu kondisi sosio-ekonomi, budaya, politik, serta iptek sebagai landasan penngkatan kualitas hidup atau peningkatan kualitas sumber daya umat.

Di samping itu, ia juga menyumbang pemikiran tentang cara peningkatan mutu muballigh atau da'i dan pengelolaan kegiatan masjid dan majlis ta'lim yang meliputi: (1) pengetahuan tentang sumber-sumber pokok ajaran Islam; (2) kemampuan muballigh memahami kondisi sosial, budaya, ekonmi dan politik umat; (3) pengetahuan mubaligh tentang perkembangan iptek; (4) perkembangan masyarakat dan masalah kemanusiaan baik dalam kerangka kehidupan bangsa maupun dunia internasional lainnya; dan (5) kemampuan muballigh dan pengelola masjid serta pengajian dan majlis ta'lim dalam mengelola sumber belajar dan potensi umat (Mulkhan, 1995: 31).

Ia juga tetap konsisten dalam dakwah Muhammadiyah sebagai gerakan pemurnian untuk mengajak kembali kepada al-Quran dan asSunnah (ruju' ila al-Quran wa as-Sunnah) sebagai sikap kritis. Menurutnya (1995: 43),

Gagasan kembali kepada al-Quran dan as-Sunnah adalah kritisisme intelektual dan kemanusiaan, sekaligus merupakan spiritualisasi yang membebaskan perysarikatan dari kejenuhan rutinitas gerakan karena selalu ada harapan dan peluang munculnya gagasan baru yang lebih segar sebagai kekuatan penggerak yang tak pernah lelah. Kritisisme merupakan bentuk operasional kegelisahan iman yang selalu aktual sehingga kebijakan konseptual dan amaliah gerakan merupakan spirituaslisasi gerakan sebagai paradigma pengembangan gerakan Islam dalam alam kehidupan modern.

Menurutnya (1995: 198), dakwah amar ma'ruf nahi munkari sesungguhnya dapat disebut sebagai basis ontologis pandangan hidup Muhammadiyah. Organisasi, ditempatkan sebagai sistem mobilisasi dan 
aktualisasi sumber kekuatan manusia yang pluralistis dengan tujuan ideal kesejahteraan kehidupan manusia dan masyarakat bangsa, sehingga pengorganisasian dakwah dapat disebut sebagai paradigma kesalehan kemanusiaan dan kemasyarakatan kebangsaan.

Selain itu, Mulkhan juga mengenalkan istilah Islam Murni dalam Masyarakat Petani, judul disertasinya yang telah dibukukan. Menurutnya (2000: xi-xii), terdapat empat varian anggota Muhammadiyah sebagaimana hasil risetnya, yaitu: Islam murni (kelompok al-Ikhlas), Islam murni yang tidak mengerjakan sendiri tapi toleran terhadap praktik TBC/takhayul-bid'ah-churafat (kelompok Kiai Dahlan), neotradisionalis (kelompok Munu, Muhammadiyah-NU), dan neosinkretis (kelompok Munas, Muhammadiyah-Nasionalis atau Marmud, Marhaenis-Muhammadiyah).

Pandangan yang pernah mengguncang kategorisasi wajah Muhammadiyah ini bisa dimaklumi, mengingat tuntutan paradigma sosiologis Mulkhan untuk semakin akomodatif dan toleran dalam mengapresiasi realitas-objek material yang dikajinya. Apa yang dimungkinkan bagi "jalan baru" Islam itu sebenarnya adalah pengejawantahannya dalam menantang generalisasi subjektivistik yang cenderung intoleran yang telah lama dipupuk oleh segelintir intelektual non-Muhammadiyah ataupun Muhammadiyah "ortodoks"-yang mengambil sikap a priori dan tindakan sentimentil—sebagai upaya untuk menjelaskan duduk persoalan yang kompleks yang tidak secara gegabah bisa dipukul rata oleh sebuah perspektif negatif atau semacam sesat pikir.

Inilah kemudian yang dimengerti sebagai terobosan mutakhir pemetaan wacana atas realitas sosial Muhammadiyah di penghujung abad ke-20 — dalam masyarakat petani versi Mulkhan-yang diharapkan bisa membuka mata para pembaca realitas Muhammadiyah pada saat itu. Apakah kemudian tesis ini masih berlaku bagi perguliran wacana kritis yang secara intensif senantiasa menggelinding seiring dengan pro dan kontra soal pergerakan Muhammadiyah sampai saat ini? Sangat tergantung dari seberapa besar kepentingan seseorang dalam menerimanya sebagai fakta dan mencermatinya kembali sebagai sebuah ide gemilang yang masih wajar untuk selalu diperbarui dan dikritisi (Abror, 2005b: 36).

Pembaruan versi Mulkhan adalah tawaran alternatif yang sangat mungkin bisa memberikan solusi, atau paling tidak, jalan keluar bagi 
kebuntuan gerakan ini. Ada semacam nuansa demoktratisasi wacana atau liberalisasi budaya lokal yang hendak diangkat Mulkhan setaraf dengan budaya-budaya liberal global, dalam arti memiliki hak-hak yang sama untuk mengambil keputusan kreatif atas dasar kearifan atau aksesoris budaya lokal. Narasi-narasi lokal-meminjam istilah postmodern Lyotard-berhak secara otonom tampil dengan multiwajah dan siap menawarkan pelbagai sentuhan yang berbeda atau langgam multiplisitas, sebagaimana yang selama ini dienyam oleh narasi-narasi besar (grand narratives), seperti ketundukan pada sistem ketaksadaran kolektif yang telah menjadi hal biasa, pola penindasan yang bisa dinikmati versi kapitalisme global misalnya. Persoalannya terletak pada dua hal yang saling bertentangan, yaitu apakah model pemikiran berkeserbaragaman itu bisa mengarahkan Muhammadiyah pada pola "gerakan cinta" ataukah justru melanggengkan pola yang lama yaitu "gerakan konfrontatif". Gerakan cinta-mirip dengan istilah John D. Caputo, "agama cinta" - secara ekstrem hanyalah diperuntukkan bagi para pecinta, dalam konteks ini adalah pecinta keserbaragaman dalam soal peneguhan keberimanan. Berbeda dengan gerakan konfrontatif, yaitu suatu gerakan yang selalu konsisten, dalam hal ini misalnya, melawan TBC (takhyul, bid'ah, churafat) atas dasar doktrin bergaris keras, tanpa kompromi, atau dogmatisasi tertentu yang terlembagakan yang sedemikian kuat mengakar pada derap misi atau syiar organisasi. Yang pertama berusaha membangun karakter gerakan yang lebih inklusif, ekstrovert, dan menghargai perbedaan atas multiperspektif, sedangkan yang kedua menjadi gerakan eksklusif, introvert, yang "mau tak mau" harus diterima secara umum dan biasanya tanpa mengindahkan budaya lokal yang kompleks dan sarat perbedaan (Abror, 2005b: 36).

Sejauh ini sejak kelahirannya, sebagian pengawal ideologi Muhammadiyah masih memanfaatkan pola yang kedua-gerakan konfrontatif-yang sebenarnya justru menciptakan ketakutan bagi yang lain (the other) dan menjauhkan gairah kuriositas-kemauan untuk mendekati Muhammadiyah-yang lain menjadi gairah yang tidak simpatik, antipati, dan a priori. Sebuah agama tentu saja membutuhkan sebuah cara pendekatan, seperti strategi menjual yang kreatif yang dapat menggugah rasa penasaran dan kesadaran seseorang untuk memilihmasih ingat dengan Film Kera Sakti yang sebenarnya lebih sebagai improvisasi visual untuk menarik simpati dari segala usia penggemar tayangan TV ketimbang yang benar-benar termaktub dalam ajaran kitab Budha, atau penciptaan kreatif Barat atas budaya Valentine Day, sosok 
Sinterklas yang ramah dan pecinta anak-anak, atau seperti Zodiak (ramalan perbintangan) yang digemari remaja serta pelbagai sebutan atas tahun Cina yang dilambangkan dengan binatang dan Feng Shui-nya yang mendapat respons positif dari banyak kalangan, dll., meskipun tidak mudah pada kenyataannya membuat hal yang serupa dalam Islam atau di Muhammadiyah. Kalau saja rasa untuk memilih telah hilang, dan boleh dikata sebagai hilangnya sebuah pilihan, tampaknya inilah masalah yang paling akut dan riskan yang pasti dijauhi oleh siapapun yang menggenggam rasionalitas dan mungkin hati nurani atas nama kebijaksanaan dan realitas selera publik. Oleh sebab itu, kecenderungan pola lama dimana gerakan konfrontatif menjadi dominan haruslah digantikan, atau hijrah kepada, gerakan cinta, yang selama ini menjadi subordinan, sebagai pola gerakan baru yang berorientasi pada terciptanya cara pandang keagamaan yang lebih memanusiawikan yang harus menjadi pilihan objektif rasionalitas dan tidak bisa ditawar lagi. Gerakan cinta adalah penafsiran atas makna transformasi, atau hijrah yang sesungguhnya dari pola misi dominasi absurditas (gerakan konfrontatif) yang semakin menjauhkan pemilih atau yang lain karena indoktrinasi ideologi untuk mendapatkan legitimasi menuju model gerakan yang akomodatif dan progresif seperti hegemoni-istilah Gramsci. Atas dasar cinta-cinta pada Tuhan, kebenaran, dan kedamaian-gerakan ini bisa menggunakan tradisi hegemonis yang dapat mendamaikan kekerasan wacana kontra Muhammadiyah dengan ajaran pemurniannya. Tradisi ini bisa dilakukan dengan dua cara, yaitu: "kekerasan yang memaksa" atau "pendekatan yang mengajak". Tentu saja dipakai cara yang kedua, yaitu pola pendekatan yang mengajak, artinya Muhammadiyah bisa membuka saluran aspiratif yang mungkin ditunggangi potensi konflik kepentingan kepada saluran ideologis yang benar yang mengubahnya menjadi potensi kreatif progresif (Abror, 2005b: 37).

Tindakan retrospektif ini-pembacaan atas masa lalu (misi atau doktrin dakwah gerakan) dengan tawaran alternatif yang dicobakembangkan tadi-sangat bermanfaat dan pada gilirannya dapat dilakukan oleh kaum intelektual organik kolektif dan diharapkan mereka bisa mengatur kepentingan dominan dengan resistensi subordinan, sebuah upaya untuk mewujudkan harmonisasi antara ajaran pemurnian dan doktrin gerakan dengan realitas sosial umat manusia yang kompleks. Pada kelanjutannya, proses gerakan yang telah diawali itu kemudian dikembangkan oleh segenap organ gerakan untuk merembeskan dan 
melancarkan peredaran ide itu menjadi denyut nadi kehidupan masyarakat gerakan yang terus dipompa oleh proses pendewasaan dan kematangan umat dalam perjalanannya. Kalau ini berjalan dengan baik, maka upaya mengkonstruksi ide tentang gerakan cinta menjadi bagian penting dari pencerahan (Abror, 2005b: 37).

Sebuah gerakan tentu saja ingin melampaui ruang kesunyian yang lama merindukan ide-ide positif menuju angan-angan pencerahan yang membebaskan-meminjam definisi Kant—untuk meneguhkan komitmen dan memberi dorongan agar berani menggunakan rasio sendiri (sapere aude!). Pencerahan inilah yang membebaskan manusia dari jebakan dogmatik yang kaku dengan memberikan porsi pada akal untuk melakukan ijtihad-bertarjih versi Muhammadiyah. Jika jembatan hijrah, atau prosedur transformasi itu bisa diamini dan dibangun berdasarkan akal sehat (common sense) para elit gerakan serta mendapat dukungan optimal dan respons positif dari akar rumput, maka inilah kemudian yang dinamakan pencerahan yang sesungguhnya yang telah dirintis melalui gerakan cinta. Pencerahan selalu dinantikan oleh zamannya dan untuk menuju kepadanya dibutuhkan prosespemahaman, rasionalisasi pendekatan dan realisasi gagasan yang bertumpu pada gerakan cinta itu tadi. Resiko paling mendasar atas adanya proses itu adalah teror sentimentil massa atau sejumput elit gerakan yang terkadang tidak pernah bersedia memberikan ruang publik untuk membuka dialog secara sehat dan membangun dialektika yang wajar. Ancaman ini selalu ada dan terjadi pada gerakan manapun dan itu sebenarnya bagian juga dari keniscayaan dari pergulatan gerakan progresif melawan kemapanan represif. Hanya bila keberadaannya terlalu lama menggerogoti pondasi awal rencana membangun gerakan cinta maka tidak mustahil proses menuju pencerahan tinggal sekadar mimpi atau menyisakan utopia belaka. Untuk mewujudkan angan-angan yang mulia, pencerahan itu, dibutuhkan perlawanan, dan perlawanan yang tulus adalah desakan berjubah ketundukan sambil menyapa realitas pelan-pelan (Abror, 2005b: 37).

\section{E. Amien Rais: Masjid dan Tauhid Sosial}

Muhammad Amien Rais lahir di Surakarta, 26 April 1944. Meraih gelar Ph.D. dalam bidang ilmu politik dari Universitas Chicago, Amerika Serikat pada 1981. Dalam bukunya, Tauhid Sosial (1998) ia menulis dua 
masalah penting: "Masjid: Sumber Persenjataan Moral dan Spiritual Masyarakat Modern" dan "Risiko Mengabaikan Tauhid Sosial".

Dalam membahas tentang masjid, Amien (1998: 67-68) mengatakan bahwa masjid sesungguhnya memberikan sesuatu yang dinamakan spiritual, moral, dan ethical rearmament, yaitu persenjataan spiritual, moral dan mental untuk menangkal pelbagai kecenderungan negatif dalam masyarakat modern. Keberadaan masjid sangat penting tak terkecuali di kampus. Menurutnya, kampus yang ideal mutlak ada di dalamnya masjid semegah dan seindah bangunan-bangunan yang lain. Dalam bahasa Arab, universitas adalah al-jami'ah, sedangkan masjid adalah kata lain dari jami'. Universitas dan masjid berasal dari akar kata yang sama sehingga keduanya sangat dekat dan tidak dapat dipisahkan. Mengutip pernyataannya (1998: 68),

Masyarakat kita yang makin terindustrialisasi, makin modern sehingga, cepat atau lambat, masyarakat modern dengan segala ciri positif dan negatifnya pasti tiba dengan adanya globalisasi dunia. Invasi masyarakat modern internasional ke dalam masyarakat kita akan luar biasa bila tidak siap-siap. Dan yang bisa menangkal dan mematahkan invasi kultural yang negatif itu hanya masjid. Karena, pada intinya, selain merupakan pendidikan disiplin, demokrasi, kebersamaan, tanggung jawab, dan lain-lain, masjid juga merupakan sumber persenjataan moral dan spiritual.

Sebagai sumber persenjataan moral dan spiritual, masjid menjadi tempat yang tepat untuk menyusun strategi dakwah dan merumuskan pelbagai pemikiran yang kontributif bagi umat Islam. Islam sebagai agama yang membebaskan umat dari invasi kultural negatif sangat bergantung dari eksistensi jama'ah untuk memberi makna kepada masjid. Munculnya Islam sebagai agama di dunia ini tak dapat dipungkiri telah membawa rahmat bagi para pemeluknya sekaligus ancaman yang jelas atas segala bentuk kemapanan keagamaan yang ada sebelumnya. Yang pertama tentu saja erat kaitannya dengan janji-janji Islam yang telah dengan bijaksana mengemas ongkos sosial umatnya (iman dan amal shalih) di dunia dengan perolehan-perolehan akhirat berdasarkan pencapaian-pencapaian itu-meskipun dicurigai sebagai imajinasi atau ilusi secara ekstrem tetapi itulah realitas Ilahi yang tersembunyi. Yang kedua, karena kemunculannya itu, Islam tidak jarang dipandang sebagai sarat pertentangan dan gesekan bagi lawan-lawannya. Meskipun secara historis tidak ada yang dikategorikan lawan, kecuali dalam pengertian 
pembedaan kategoris saja. Agama-agama yang tampil lebih dahulu sebelumnya telah merasakan satu keistimewaan yang tak tergugat dan di balik itu semua adalah kenyataan bahwa mereka tak pernah memperoleh lawan seimbang sebagaimana ancaman Islam dalam arti ini. Oleh sebab itu, kedatangan Islam yang secara tegas ingin meluruskan pembelokanpembelokan paradigmatik yang dikembangkan oleh agama yang telah ada, bisa dianggap sangat mengkhawatirkan mengingat peran dogmatik yang diembannya begitu tangguh untuk melakukan pendobrakan.

Di sinilah yang menarik kemudian munculnya istilah tauhid, yang secara teologis berarti pengesaan Tuhan. Menarik, ketika Prof. Amien Rais mencoba "merevitalisasi" spirit tauhid dengan apa yang disebutnya tauhid sosial. Menurut Damami (2000: 122) mengutip Sobary, bahwa embrio mencuatnya nama Amien Rais salah satunya dimulai dengan hasil introduksinya atas gagasan tauhid sosial. Ia (1998b: 127; 2004a: 43) menegaskan,

Allahuyarham K.H. Ahmad Dahlan, pendiri Muhammadiyah, pernah bertahun-tahun hanya mengajarkan Surat al-Ma'un pada para santrinya. Hal itu dilakukan bukan saja karena pesan-pesan keadilan sosial dari surat itu belum dilaksanakan dengan baik oleh umat Islam, tetapi juga karena beliau ingin menanamkan satu pengertian bahwa keadilan sosial adalah realisasi "tauhid sosial" di tengah masyarakat Indonesia.

Menurut Amien Rais (1998b: 126), K.H. Ahmad Dahlan pernah berwasiat, al-dau musyarakatullahi fi jabarutihi waddawau tauhidullahi haqqan, penyakit sejati adalah menyekutukan Allah dalam hal kekuasaannya, sedangkan obat sejati adalah mengesakan Allah dengan sesungguh-sungguhnya. Bagi Amien Rais (1998: 38-43; Damami, 2000: 123) "tauhid" mengandung pelajaran moral yang terdiri dari lima tingkat. Tingkat pertama, tauhid berarti berani berkata tidak pada kebatilan dan kebtidakbenaran. Kedua, memiliki keyakinan kepada Allah swt secara penuh, yang berarti meniadakan apa-apa yang bukan Allah swt. Ketiga, mendeklarasikan diri tentang kehidupan yang dituntunkan oleh alQuran. Keempat, menerjemahkan keyakinan keesaan Allah swt dan petunjuk-Nya dalam al-Quran dalam wujud sikap budaya untuk mengembangkan amal saleh. Dan kelima, orang yang bertauhid mengambil kriteria atau ukuran baik dan buruk, terpuji dan tercela, kembali kepada al-Quran dan as-Sunnah. 
Menurutnya, upaya untuk mengimplementasikan tauhid sosial perlu didukung oleh empat doktrin yang hidup di kalangan warga Muhammadiyah, yaitu: (1) pencerahan umat; (2) menggembirakan amal shaleh; (3) kerjasama untuk kebajikan; dan (4) tidak berpolitik praktis (Amien Rais, 2004a: 44-48).

Ia mengingatkan akan risiko mengabaikan tauhid sosial, yaitu bahwa umat Islam bisa mengalami krisis relevansi (suffering from crisis of relevant). Setiap masalah tidak dicari rujukannya dari ajaran Islam tetapi justru mendapat arahan dari paham atau ideologi lain. Anak-anak muda dan para pemikir Muslim yang gandrung kepada keadilan dan pemerataan lebih mencari pijakannya dalam ideologi lain, seperti Marxisme, Leninisme atau Trotskisme. Secara tidak sengaja juga akan mengizinkan tumbuhnya sekularisme. Baginya, imaji Islam adalah agama masjid, agama ruhani, agama yang membersihkan ruhani, yang menegakkan akhlak mulia haruslah berhubungan dengan realitas sosial, jika tidak, maka orang akan lebih percaya kepada sekularisme (Amien Rais, 1998: 118-119)

Tauhid sosial adalah doktrin perjuangan Muhammadiyah. Bagi Amien Rais, sebagaimana dipaparkan oleh Hanum Salsabiela (2010: 25), bahwa Muhammadiyah adalah ladang berjuang dan berpikir bagi ayahnya. Apa yang didengungkan Amien Rais dengan tauhid merupakan pengejawantahan dakwah dalam arti sosial, yakni keterlibatannya untuk berpartisipasi secara religius dalam menegakkan keadilan dan kebenaran dalam segala aspek kehidupan duniawi ini, tak terkecuali politik. Inilah yang menimbulkan wacana pro dan kontra dalam diskusidiskusi pada saat itu. Tidak mudah meletakkan satu unsur agama yang fundamental ke dalam diskursus yang sedang berjalan. Politik menuntut dijaminnya hak-hak subjektif demi keberlangsungan kepentingan dan kekuasaan, tetapi tauhid tidak menyediakan menu yang mengumbar selera politikus atau penguasa untuk bisa bebas menikmatinya. Tidak tersedianya apa yang diinginkan dalam perspektif politis praktis inilah yang bisa menyumbat saluran-saluran produktif dalam arti kepentingan untuk mewujudkan mimpi-mimpi kreatif yang selama ini berjalan berdampingan dengan sebuah kepentingan. Tidak adanya toleransi dan ruang bersahabat dalam hal-hal negatif inilah yang juga menempatkan tauhid kemudian menjadi hantu bagi rasa politis atau horor bagi selera penguasa (Abror, 2005a: 38). 
Untuk meletakkan tauhid dalam semangat gerak zaman, yang secara kontekstual senantiasa menggelinding bersama realitas sosial, maka kajian atasnya hendaknya seobjektif mungkin meredefinisinya secara lebih historis. Keberanian historis adalah bagian dari tindakan provokatif yang memungkinkan tauhid untuk bisa lebih dipahami dalam dimensi yang lebih luas. Kebutuhan akan investigasi sejarah inilah yang bisa mendorong semangat zaman untuk lebih bisa mengerti akan progresivitas tauhid ini. Kalau tauhid dijelmakan dalam berbagai muka, dengan tambahan kata di belakangnya apa saja misalnya, tidak mengurangi ketakutan dunia untuk mengadopsinya bagi kemaslahatan umat manusia. Lain halnya kalau makna religius yang disucikan dalam alQur'an bisa diberi penafsiran yang menzaman, yang lebih akomodatif, yang mengerti akan tuntutan-tuntutan dari keseluruhan yang kompleks di dunia realitas ini. Apa yang menjamin bahwa tauhid akan bisa ditegakkan dan dirasakan dalam sebuah kenikmatan sosial adalah keterbukaan interpretatif atasnya yang dengan demikian selalu berusaha mencari pendekatan-pendekatan alternatif yang lebih mencerahkan (Abror, 2005a: 38).

Tauhid menjadi barang mati kalau diartikan secara definitif—selalu dikatabendakan-dan itu tidak akan mengubah pelebaran kesenjangan selera sosial yang kompleks dengan hasrat untuk hidup yang benar menurut Islam. Tauhid harus dimaknai sebagai kata kerja yang memberikan peluang bagi selera untuk membiarkan rasa memberikan maknanya sendiri pada peneguhan keberimanan. Sebagai usaha pelegitimasian yang realistis, hanya jika tauhid diterjemahkan dalam context of discovery bukan context of justification. Dalam konteks yang pertama inilah tauhid ditelusuri spirit terdalamnya yang tersembunyi dalam kerak geologis penafsiran yang begitu pejal agar pencarian makna yang dikandungnya menjadi kokoh karena ditopang oleh keberanian berusaha kritis yang selalu dan selalu dilakukan sebagai sebuah prosesdimengerti sebagaimana ia sebagai kata kerja. Pengertian yang diperoleh akan mempersempit ketegangan epistemologis yang selama ini terjadi antara kaum ortodoks dan pembaharu. Polarisasi pemaknaan yang mengkristal dapat ditengahi oleh kemauan atas keberbedaan perspektival sejauh sama-sama dalam rangka peneguhan keberimanan (Abror, 2005a: 39).

Atas dasar itulah tauhid akan memiliki sebuah semangat zaman yang disebut sebagai spirit pembebasan. Daya liberatif (pembebasan) 
yang dilahirkan olehnya merupakan potensi intensitas energetikbahasa postmodern Lyotard-untuk mendobrak kemapanan yang memperoleh justifikasi dari selera yang salah. Manusia punya "selera yang tak bisa diperdebatkan" (de gustibus non est disputandum), tetapi perdebatan soal hal itu tak pernah selesai karena tidak adanya standar etis yang berdasarkan norma moral. Dikatakan "bebas", hanya jika sesuatu itu memenuhi standar tertentu dalam satu aturan main. Jika itu terpenuhi, maka kata itu berubah menjadi "membebaskan" atau dalam padanannya "pembebasan". Proses hijrah dari bebas yang berkonotasi tidak selalu negatif menuju pembebasan yang sarat spirit, semangat untuk berubah, inilah yang selayaknya diberi porsi secara proporsional dalam pengejawantahan tauhid dalam menimang pelbagai rasa negatif, kepentingan yang selalu siaga mengisi perut realitas sosial (Abror, 2005a: 39).

Konsepsi Islam atas tauhid sebagai spirit pembebasan seperti itu memperbarui definisi ortodoks yang menjaganya dalam makna reifikatif yang membeku. Ketundukan pada pengesaan Tuhan, bukan saja berhenti pada pemaknaan harfiah yang eksklusif seperti itu, tetapi terkait pula apa saja yang berhubungan dengannya. Ketundukan bukan hanya rasa takut kepada Tuhan dan merefleksikannya dalam penegakan sholat, tetapi juga menempatkan rasa itu pada aspek sosial, takut kalau berbuat zalim, takut akan dampak penindasan, takut berbuat sewenang-wenang, karena adanya sanksi sosial dan kolektif, dst. Pemaknaan yang terakhir menghilangkan represivitas wacana yang lebih ideologis untuk diubah menjadi, atau hijrah kepada, progresivitas diskursus yang lebih dinamis dan menzaman (Abror, 2005a: 39).

\section{F. Penutup}

Dakwah kontemporer membutuhkan tidak saja komitmen keislaman dari para aktivis dakwah tetapi juga pemikiran rasionalfilosofis yang mampu menggelorakan spirit dakwah mereka. Kuntowijoyo, Munir Mulkhan, dan Amien Rais menyumbangkan gagasan penting bagi strategi dakwah yang lebih dinamis, ilmiah, dan kontekstual untuk mengajak kita berpikir kritis bahwa redefinisi atas konsep-konsep kunci dalam ajaran Islam-seperti masjid, teologi dakwah, dan tauhid sosial-sangat diperlukan sebagai upaya reproduksi makna dakwah itu sendiri. Kebangkitan dakwah dan kesuksesannya sangat ditentukan oleh kecerdasan, kesabaran dan keuletan para aktivis dakwah dalam 
menghadapi realitas sosial dan tantangan globalisasi, di samping komitmen keislaman sebagai basis ontologis aktivitas dakwah.[] 


\section{DAFTAR PUSTAKA}

Al-Quran al-Karim

Abdullah, Amin, dkk. (2003). Pedoman Hidup Islami Warga Muhammadiyah. Yogyakarta: Suara Muhammadiyah.

Abror, Robby H. (2005a). 'Islam, Epistemologi Tauhid, dan Spirit Pembebasan,' dalam Suara Muhammadiyah. No.11 Th. Ke-90, 1-15 Juni 2005

(2005b). 'Islam Murni, Gerakan Cinta, dan Pencerahan,' dalam Suara Muhammadiyah. No.21 Th. Ke-90, 1-15 Nopember 2005.

(2006). 'Kebenaran (Agama), Kemajuan, dan Persimpangan Maknanya', dalam Suara Muhammadiyah. No. 23 Th. Ke-91, 1-15 Desember 2006.

Amien Rais, M. (1998a). Tauhid Sosial: Formula Menggempur Kesenjangan. Bandung: Mizan

(1998b). Membangun Politik Adiluhung: Membumikan Tauhid Sosial, Menegakkan Amar Ma'ruf Nahi Munkar. Bandung: Zaman Wacana Mulia

(2004a). Visi dan Misi Muhammadiyah. Yogyakarta: Suara Muhammadiyah

. (2004b). Hubungan antara Politik dan Dakwah: Berguru kepada M. Natsir. Bandung: Mujahid Press

Anggaran Dasar dan Anggaran Rumah Tangga Muhammadiyah. (2005). Yogyakarta: PP Muhammadiyah

Asti, B.M. (2004). Berdakwah dengan Menulis Buku. Bandung: MQ

Bahtiar, Asep Purnama. (2004). Membaca Ulang Dinamika Muhammadiyah: Wacana di Seputar Pergerakan, Kepemimpinan, dan Perkaderan. Yogyakarta: LPPI UMY

Damami, Mohammad. (2000). Akar Gerakan Muhammadiyah. Yogyakarta: Fajar Pustaka

Faqih, A.R., dkk. (2006). Dasar-dasar Retorika Dakwah. Yogyakarta: LPPAI UII 
Hadjid, K.R.H. (2011). Ajaran K.H. Ahmad Dahlan dengan 17 Kelompok Ayat-ayat al-Quran. Yogyakarta: Lembaga Pustaka dan Informasi PP Muhammadiyah

Ikhsan, M., dkk. (2002). Islamisasi Kampus dan Ilmu Pengetahuan. Yogyakarta: LPPI UMY

Kuntowijoyo. (1985). Dinamika Sejarah Umat Islam. Yogyakarta: Shalahuddin Press

Muchlas, Imam. (2006). Landasan Dakwah Kultural: Membaca Respon alQuran terhadap Adat Kebiasaan Arab Jahiliyah. Yogyakarta: Suara Muhammadiyah

Mulkhan, Abdul Munir. (1995). Teologi Kebudayaan dan Demokrasi Modernitas. Yogyakarta: Pustaka Pelajar

(2000). Islam Murni dalam Masyarakat Petani. Yogyakarta: Bentang Budaya

Muria, Siti. (2000). Metodologi Dakwah Kontemporer. Yogyakarta: Mitra Pustaka

Nashir, Haedar. (2001). Ideologi Gerakan Muhammadiyah. Yogyakarta: Suara Muhammadiyah . (2006). Manifestasi Gerakan Tarbiyah. Bagaimana Sikap Muhammadiyah? Yogyakarta: Suara Muhammadiyah

Nashir, Haedar dan Maarif, A. Syafii. (2005). Dakwah Kultural Muhammadiyah Pimpinan Pusat Muhammadiyah. Yogyakarta: Suara Muhammadiyah

Nuh, Sayyid Muhammad. (2004). Strategi Dakwah dan Pendidikan Umat. terj. A. Muzammil. Yogyakarta: Prisma Media

Pasha, Musthafa Kamal, dan A. Adaby Darban. (2003). Muhammadiyah sebagai Gerakan Islam dalam Perspektif Historis dan Ideologis. Yogyakarta: LPPI

Salsabiela Rais, Hanum. (2010). Menapak Jejak Amien Rais: Persembahan Seorang Putri untuk Ayah Tercinta. Jakarta: Esensi Erlangga Group

Sholeh, A. Rosyad. (2005). Manajemen Dakwah Muhammadiyah. Yogyakarta: Suara Muhammadiyah

Suparta, Munzier dan Herni, Harjani (ed.). (2003). Metode Dakwah, Jakarta: Kencana 